\title{
Correction to: Baseline-adjusted proportional odds models for the quantification of treatment effects in trials with ordinal sum score outcomes
}

\author{
Muriel Buri ${ }^{1}$, Armin Curt ${ }^{2}$, John Steeves ${ }^{3}$ and Torsten Hothorn ${ }^{1 *}$
}

\section{Correction to: BMC Med Res Methodol (2020) 20:104 https://doi.org/10.1186/s12874-020-00984-2}

Following publication of the original article [1], the authors would like to correct the formula of the Polr model equation in the paragraph under the heading Enhanced proportional odds logistic regression (ePolr).

The formula currently reads:

$$
\mathrm{P}\left(\mathrm{Y}^{\mathrm{III}} \leq \mathrm{y}^{\mathrm{III}} \mid x\right)=\operatorname{expit}\left(h\left(\mathrm{y}^{\mathrm{III}} \mid \mathrm{y}^{0}\right)+\beta \cdot x\right)(\text { Polr })
$$

The formula should read:

$$
\mathrm{P}\left(\mathrm{Y}^{\mathrm{III}} \leq \mathrm{y}^{\mathrm{III}} \mid x\right)=\operatorname{expit}\left(h\left(\mathrm{y}^{\mathrm{III}}\right)+\beta \cdot x\right)(\text { Polr })
$$

The original article [1] has been corrected.

\begin{abstract}
Author details
'Department of Biostatistics, Epidemiology, Biostatistics and Prevention Institute, University of Zurich, Hirschengraben 84, CH-8001 Zurich, Switzerland. ${ }^{2}$ University Hospital Balgrist, Spinal Cord Injury Center, Forchstrasse 340, CH-8008 Zurich, Switzerland. ${ }^{3}$ International Collaboration On Repair Discoveries (ICORD), University of British Columbia, Vancouver/ Kelowna, Canada.
\end{abstract}

Published online: 09 July 2020

\section{Reference}

1. Buri, et al. BMC Med Res Methodology. 2020;20:104. https://doi.org/10.1186/ s12874-020-00984-2.

\footnotetext{
The original article can be found online at https://doi.org/10.1186/s12874020-00984-2.

*Correspondence: torsten.hothorn@uzh.ch

1 Department of Biostatistics, Epidemiology, Biostatistics and Prevention Institute, University of Zurich, Hirschengraben 84, CH-8001 Zurich, Switzerland

Full list of author information is available at the end of the article
}

(C) The Author(s). 2020 Open Access This article is licensed under a Creative Commons Attribution 4.0 International License, which permits use, sharing, adaptation, distribution and reproduction in any medium or format, as long as you give appropriate credit to the original author(s) and the source, provide a link to the Creative Commons licence, and indicate if changes were made. The images or other third party material in this article are included in the article's Creative Commons licence, unless indicated otherwise in a credit line to the material. If material is not included in the article's Creative Commons licence and your intended use is not permitted by statutory regulation or exceeds the permitted use, you will need to obtain permission directly from the copyright holder. To view a copy of this licence, visit http://creativecommons.org/licenses/by/4.0/. The Creative Commons Public Domain Dedication waiver (http://creativecommons.org/publicdomain/zero/1.0/) applies to the data made available in this article, unless otherwise stated in a credit line to the data. 